\title{
Antwoorde op prikkelende geloofsvrae
}

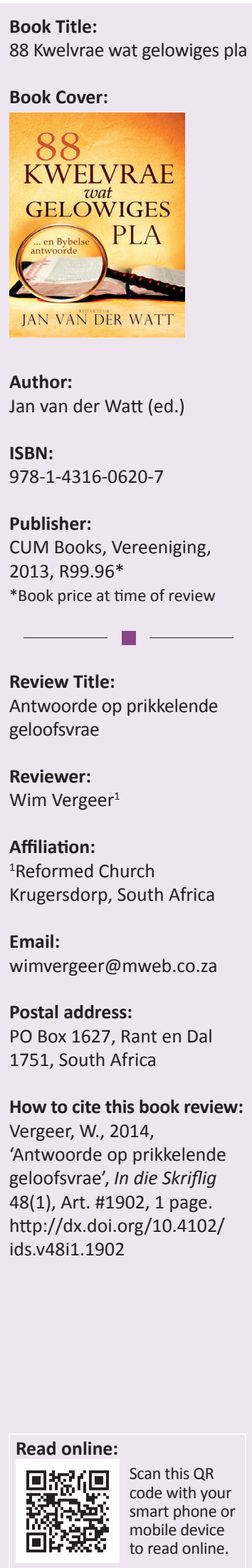

Die gesoute teoloog, Jan van der Watt, tree as redakteur op vir die publikasie wat handel oor 88 kwelvrae wat gelowiges pla. Hy is self die skrywer van die meeste (54) van die antwoorde wat op die kwelvrae gegee word, terwyl bydraes ook deur bekende skrywers soos Stephan Joubert (6), Hermie van Zyl (3), Adrio König (5), Kobus Kok (7), Milanie Vosloo (7), Francois Malan (5), Coen Slabber (2) en Johan Smith (1) gelewer word. By sommige van die vrae word die antwoord gesamentlik deur meer as een persoon voorsien. Nie al die antwoorde is egter nuutskeppings nie - sommige antwoorde is voorheen in ander werke van die betrokke outeurs gepubliseer.

Die oorsprong van die 88 kwelvrae lê by die webblad www.bybelkennis.co.za - 'n webwerf wat daarop toegespits is om meer inligting oor die Bybel te verskaf en waarby teoloë uit 'n groot verskeidenheid Afrikaanse denominasies betrokke is. Met die skryf van hierdie resensie is die webwerf (sedert sy ontstaan) al meer as 500000 keer besoek. Vrae wat deur mense op hierdie blad geplaas is, asook die antwoorde wat deur teoloë aanlyn verskaf is, is in hierdie publikasie verwerk. Daar is dus duidelik gevoel dat die vrae en antwoorde ook buite die kuberruim, vir 'n breër publiek van waarde kan wees.

Teen hierdie agtergrond is dit te wagte dat ' $n$ hele hutspot vrae spontaan in die publikasie aan die orde sal kom. Sommige vrae is eties-moreel van aard (dobbel, egskeiding, poligamie), ander is prakties (finansies, gebed, sondebelydenis) terwyl nog ander oor ingewikkelde filosofiese en teologiese sake gaan (dood, wedergeboorte, doop). Die vlak waarop die vrae beantwoord word, verskil. In dieselfde publikasie word die vraag of die duiwel 'n mens se gedagtes kan lees byvoorbeeld kursories in een paragraaf hanteer, terwyl daar in tien bladsye uitvoerig ingegaan word op die vraag watter Bybelvertaling reg is.

Noodwendig verskil ook die styl waarin die onderskeie outeurs die vrae hanteer. In sommige gevalle word bloot inligting voorsien en word dit aan die leser self oorgelaat om 'n keuse te maak (swaarkry). In ander gevalle word daar erken dat daar te min inligting is om ' $n$ vraag presies te antwoord (Jesus se geboortedatum). In nog ander gevalle word daar pertinente antwoorde voorsien (Kan iemand wat dood is nog gered word?).

Deurgaans is die indruk egter dat elke outeur daarvan erns maak om die lig van die Bybel op verskillende vraagstukke en temas te laat skyn. Ou bekende waarhede en verrassende nuwe feite volg mekaar in die publikasie op, met die gevolg dat interessante materiaal vir 'n wye spektrum van lesers beskikbaar gestel word. Die publikasie sal goed as leesstof op die bedkassie deug en dit kan selfs handig wees vir klein- of selgroepe wat 'n bepaalde vraag tydens hulle byeenkoms as besprekingspunt wil hanteer.

Soos 'n mens al gewoond geraak het van CUM-publikasies, is die leesbaarheid, versorging en aanbieding van die boek van hoogstaande gehalte. 